\title{
Ambivalent Mobilities and Survival Strategies of Moroccan and Bangladeshi Families in Italy in Times of Crisis
}

\section{Francesco Della Puppa}

Ca' Foscari University, Venice, Italy

\begin{abstract}
This article investigates the link between the economic crisis and migrant family reunification with a focus on mobility strategies of reunited families. Drawing on in-depth interviews with Moroccan and Bangladeshi families, carried out in the Metropolitan City of Venice, between 2012 and 2016, the article aims to show the complex process of further separation that reunified families endure in order to deal with the consequences of the crisis. Family unity does not represent a definitive and lasting achievement. Rather, it is a status that must be constantly protected in order to fulfil the requirements imposed by reunification policies. Migrant families must undertake various forms of mobility to maintain their housing, occupational and economic standards and sometimes may move to other countries to preserve their unity. In response to the crisis, migrants appropriate the instruments of citizenship in order to increase their mobility capital and the opportunity to stay in Europe.
\end{abstract}

\section{Keywords}

citizenship, economic crisis, family reunification, Italy, migrant family, mobility, motility, onward migration

\section{Introduction}

The economic crisis has had a profound impact on international migration in many respects, especially in Mediterranean Europe (Lafleur and Stanek, 2017). The flow of migration in the countries of destination would seem to have declined, the amount of remittances has fallen and, obviously, the employment dynamics of migrants - as well as their biographical, social and family trajectories - have been greatly transformed (Mosern and Horne, 2015).

\section{Corresponding author:}

Francesco Della Puppa, Department of Philosophy and Cultural Heritage, Ca' Foscari University in Venice, Dorsoduro 3484/D - 30123, Venice, Italy.

Email: francesco.dellapuppa@unive.it 
In recent years, sociological studies that investigated the relationship between the crisis and migration have focused mainly on the significant deterioration of the employment conditions of migrants (Bonifazi and Marini, 2014; Spitzer and Piper, 2014; Tilly, 2011). This article, based on in-depth interviews with migrants, examines the impact of the economic crisis on family unity, achieved through family reunification, of Moroccan and Bangladeshi migrants in Italy. Specifically, taking into account the 'migration seniority' in Italy of reunited families and their structure, it analyses the nexus between the crisis and mobility in the Metropolitan City of Venice, delving into the different survival strategies adopted by migrants to protect their family unity. The article shows how reunited migrant families have undertaken various forms of mobility and redefined their daily geographies in order to maintain their occupational status and make economic savings so that they can retain the material requirements of reunification policies, including certain conditions relating to income and housing.

Following this introduction, the article proceeds as follows. The first section introduces the theoretical issues related to the impact of the crisis on migrant families, the concept of citizenship and the multiple shapes of migrant family. A methodological section then follows. The third section analyses the survival strategies and mobility deployed nationally (or locally) by Moroccan and Bangladeshi migrant families to deal with the crisis. Finally, the fourth section deepens those strategies that include an international dimension. Within this framework, a pivotal role is played by the acquisition of Italian citizenship, which serves as both as tool for stabilisation and as a way to achieve European mobility.

\section{Migration Scenarios Change in Times of Crisis}

\section{Migration, Economic Crisis and Citizenship}

Several sociological studies (Bonifazi and Marini, 2014; Spitzer and Piper, 2014) have investigated the ways in which the effects of the economic crisis hit Mediterranean Europe and Italy, suggesting that the impact has been particularly intense among migrants (Awad, 2009; Martin, 2009; Tilly, 2011). However, it did not increase return migration (Boccagni and Lagomarsino, 2011) and migrants have generally stayed in their destination country, preferring to adopt a number of survival strategies, such as reducing expenditure and remittances to their country of origin (Triandafyllidou, 2014); taking on multiple jobs (Sacchetto and Vianello, 2013); moving to cheaper housing or considering further mobility (Della Puppa and Sredanovic, 2017; Jackson et al., 2014; Spitzer and Piper, 2014). The crisis has also contributed to the relatively new phenomenon of 'onward migration' within Europe (Giralt-Mas, 2017): the reactivation of mobility by 'third country nationals' (TCNs) who, once they have acquired European Union citizenship, leave for another EU country (Ahrens et al., 2016; Rezaei and Goli, 2011; Toma and Castagnone, 2015; Van Liempt, 2011).

The traditional view of citizenship sees naturalisation as permanent settlement within the society of which one becomes a citizen (Bloemraad, 2004). However, some studies (Codini and D'Odorico, 2007; Colombo et al., 2011) show that the aim of acquiring Italian citizenship is instrumental to further movement to other countries. EU citizenship is the 
final goal of the settlement path for some TCN migrants, while others see formal citizenship as a means of obtaining the freedom to pursue a further migration (Danaj and Çaro, 2016; Della Puppa and Sredanovic, 2017). Such dual meaning of formal citizenship recalls the paradigm of 'mobility' (Morokvasic, 2004) and its implications in terms of unequal opportunities (Faist, 2013; Glick Schiller and Salazar, 2013). Mobility acquires different meanings dependent on the legal structure of opportunities: as Italy is part of the EU and the Schengen Area, an Italian passport is particularly desirable. For non-EU citizens, it increases the potential for movement within European space, constituting, perhaps, a unique context in terms of opportunity for international mobility. Kaufmann et al. (2004) frame such potential mobility as a form of capital - pursued through the acquisition of EU citizenship - defining it in terms of 'motility'.

At the same time, especially in times of crisis, mobilities are sometimes chosen, are sometimes unwanted (even if not forced) and are not necessarily either traumatic or successful. Certainly, EU citizenship has implications for migrant family strategies and for the mobility opportunities that it allows. Moreover, in recent sociological literature, the theme of mobility is more frequently dealt with in terms of international or transnational mobilities (Andrijasevic and Sacchetto, 2016; Favell, 2014), which ignores national or local, daily or weekly forms of mobility (Champion and Shuttleworth, 2017; Clark et al., 2017) and rarely addresses the family perspective.

\section{The Multiple Shapes of Migrant Family: Transnational, Reunited, 'Nuclearised', 'Re-Transnationalised'}

Despite official rhetoric that prioritises economic migration (and, recently, the flow of refugees), the main reason for migration in the majority of European countries is still family reunification (Castles et al., 2013). It should be also emphasised that these two types of migration are closely linked. First, this link is directly and indirectly established by family reunification policies that, as we will see below, set material requirements that can be satisfied through the work of the first-migrant applicant. Second, reunited family members contribute to reproductive work or else became a further burden (Bonizzoni, 2014; Kofman and Raghuram, 2015). Third, they often increase the family wage by entering the formal or informal labour market.

In Italian legislation, sufficient income and suitable housing must be available before families may be reunited (Bertolani et al., 2013; Bonizzoni, 2012). On this basis, achievement of the material parameters is made possible by the income of the first-migrant applicant (Kraler, 2009) who, de facto, plays the role of 'sponsor' for reunited relatives (Strasser et al., 2009). The intersections of these parameters and the 'ethno-national' segmentation of labour (Fullin and Reyneri, 2011) and housing market structure the right to family life along national, ethnic, gender and class lines (Bertolani et al., 2013; Bonizzoni, 2012, 2015a; Schweitzer, 2015). Furthermore, Italian legislation constructs spouse and minor children as the only 'legitimate' family members eligible for reunification, while the possibility of reuniting with elderly parents is severely limited and those with other relatives are not included. Therefore, these policies produce a process that could be defined as a 'forced nuclearisation' of the migrant family (see also Bragg and Wong, 2016). The policies select subjects with productive potential rather than 
supposedly inactive and welfare-dependent populations (Askola, 2016; Eggebø, 2010). In so doing, they considerably limit the field of 'legitimate' dependencies and forms of solidarity within the migrant family (Bonizzoni, 2012, 2015a). The imposition of the 'nuclear family paradigm' (Mustasaari, 2015) in the country of destination - which impacts especially on newly reunited families - hardly reflects the reality experienced by migrants in their countries of origin. This makes reunited families more vulnerable. For example, with regard to the lack of extended family support in terms of economic backing, co-habitation and the sharing of care responsibilities. This may imply the emergence of new mobilities, further separations and transnationalisation.

'Transnational families', family units whose members live in different countries, is an emerging aspect of migration dynamics (Baldassar and Merla, 2014; Parreñas, 2005; Ryan, 2011). As attention is particularly focused on the transnational distance between adult parents and children, the literature has largely analysed distance parenting and care (Bonizzoni, 2015b; Bonizzoni and Boccagni, 2013; Carling et al., 2012; Dreby, 2006; Kilkey and Merla, 2014), with an emphasis on the implications of the mother-child relationship (Avila and Hondagneu Sotelo, 1997; Fresnoza-Flot, 2009). As Parreñas (2001) argues the 'pain of transnational parenthood' is a constituent element of migrant women's identities. These mothers face the physical separation of migration and, often, being stigmatised in their countries of origin and conflict between the genders within their own families. In order to relieve, at least partially, the emotional cost of their absence from home, they make use of forms of distance care such as economic remittances, frequent phone calls, the opportunities offered by the internet, traditional letters, personalised gifts and visits whenever possible (Ambrosini, 2014; Avila and Hondagneu Sotelo, 1997; Bonizzoni, 2012; Bryceson and Vuorela, 2002; Parreñas, 2008).

Therefore, within the analysis of transnational families, migrant women have been observed as mothers, transnational carers and, at the same time, breadwinners for their family members, including older parents (Baldassar, 2014). However, migrant fathers, despite the distance from their family contexts, have only rarely been identified for their transnational family experience and their role as distance carers. In this regard, some important contributions, framing male migration as an experience that redefines the identities of men and their relations with the families left behind, must be mentioned. Parreñas (2008), for example, by observing the family through an 'emotional lens' and the intersections between genders and generations, analyses the suffering and embarrassment associated with the loss of confidence between fathers and children. She also analyses the 'emotional gap' arising between generations divided by migration and how fathers and mothers manage distance care through different styles of 'frontering' (Bryceson and Vuorela, 2002). In contrast, Bustamante and Alemàn (2007) point out that fathers succeed in preserving their intimacy with their children and overcoming their physical distance to an extent through transnational caring practices similar to those of migrant mothers.

The 'pain of transnational parenthood' and distance care involves men even more with regard to forced 're-transnationalised' families. This often happens with many reunited families in Mediterranean Europe who face new separations, as a result of either further migration to Northern Europe or return to the country of origin. 
Therefore, family 'nuclearisation' as a result of reunification policies, makes reunited families more vulnerable with respect to the economic crisis and ready to separate and transnationalise again.

\section{Methods}

The empirical material for this article consists of 40 in-depth semi-structured interviews with Moroccan and Bangladeshi members of reunited migrant families, 15 of which are resident in the Province of Venice, while five were interviewed in the UK or France, as they had left Italy.

All interviewed families have completed their family reunification in the province and are practising or planning to practise different strategies and mobilities, which have been considered and analysed. In the case of all the couples interviewed, the first-migrant family member and the family reunification applicant and 'sponsor' has been a man (husband and/or father) who, consistent with family reunification policies, is or was also the family breadwinner. The youngest interviewees are in their 30 s, the oldest 55 , and all have children born or reunited with in Italy.

Moroccan husbands arrived in Italy between 1983 and 1998 and their wives arrived, through family reunification, between 1995 and 2005; while Bangladeshi husbands arrived between 1990 and 2005 and their wives between 2003 and 2010.

Ten Moroccan couples have been interviewed: among the husbands there are eight Italian citizens and two long-term residents, while among the wives there are nine Italian citizens and one long-term resident. Similarly, among Bangladeshi husbands of the 10 interviewed couples, there are four Italian citizens, five long-term residents and one short-term resident, while among their wives, there are nine long-term residents and one short-term resident.

Fieldwork was carried out between January 2012 and December 2016. Interviewees were accessed mainly by 'snowballing' from a variety of initial approaches in order to maximise participant heterogeneity. Some respondents were contacted via key informants.

The interview schedule included questions about social background in the country of origin and reconstruction of migration experience; reconstruction of family reunification and work and family life in the Province of Venice; impact of the economic crisis on family biographies; survival strategies and mobilities experienced; citizenship paths; concerns and plans for the future.

Interviews were conducted in Italian except those with Bangladeshi migrants which have been conducted both in Italian and English, according to the interviewees' inclination.

The collected material has been analysed, starting with an integral reading of the interviews one by one, followed by a codification of the various thematic segments and a horizontal comparison between the interviews.

I use the term 'applicant' (e.g. 'applicant husband') to identify the family member who brought his family members to Italy through family reunification, the term 'reunited family member' (e.g. 'reunited wife') to identify those arrived in Italy, the term 'first-migrant' to identify the family member who first migrated, opening the family 'migration chain' 
(often coinciding with the applicant family member). Interviewees' names have been changed to preserve anonymity.

\section{'Local' Strategies and National Mobilities}

Family unity is often a condition that is never achieved in perpetuity. Rather, it is a status that must be constantly protected and that is called into question by migration policies and material requirements (Bertolani et al., 2013). The crisis has led families to adopt different strategies to survive and cope with the difficulties so as to avoid losing their hard-won status of reunited family. Below, the strategies and mobilities deployed at local and/or national level by migrant families are discussed and analysed.

\section{Renewed Housing Mobilities and New Forms of Cohabitation}

Housing mobility is often the first strategy adopted by migrant families in order to maintain the conditions of reunification policies and to protect their unity. It is often characterised by forms of cohabitation between multiple families within the same urban centre where the reunited family has settled.

To optimise costs, at the time of their arrival, migrant men in Italy usually spend a period of cohabitation with fellow countrymen. At first, they usually settle in metropolitan areas and move after a period to smaller localities/areas in the provinces. This shift is driven by the search for employment and to provide administrative and housing conditions for family reunification. The economic crisis and employment difficulties have exacerbated the living standards of many migrant families. This has meant that many respondents returned to cohabitation with fellow countrymen and their families, in part also because of the absence of the extended family circle and its support. This is the case, for example, of Shantu:

There is the crisis, so I cannot pay. I made a deal with a friend, because he needs an apartment. He and his family live with me and my family and we share the costs. He's married and has two children here. Me too. It's difficult, but we have no choice. (Shantu, Bangladeshi applicant husband)

\section{The Breadwinner's Daily Commute}

The crisis in the shipbuilding industry in Marghera ${ }^{1}$ area, outside Venice, and the closure of many factories has resulted in a loss of jobs for many workers, including those who have reunited with their families. Many of these workers travel to other industrial districts outside Venice Province and its region.

In order to maintain the income they need - both to satisfy their families' material needs and to meet the legislative parameters required for the renewal of residence permits - new forms of labour mobilities take place, with inter- and intra-regional commutes that involve a significant investment of time, as Reevu clearly describes:

I [have] always worked in Mestre ${ }^{2}$ for a company subcontracted to Fincantieri, ${ }^{3}$ because that firm that works in Monfalcone ${ }^{4}$ also [works] here. But now I'm starting to work in Monfalcone. 
I go there by train, every day... I wake up and then at 5 a.m. I've to catch a train. I arrive at 7:00 a.m. and I begin to work at 7:30 a.m. I finish at 5:30 p.m., take the train to come back and arrive in Mestre at 8:30 p.m. So, in the evening I'm very tired: having dinner and go to bed. Nothing more. (Reevu, Bangladeshi applicant husband)

Paradoxically, this coping strategy, intended to protect family unity, involves a reduction in the time that migrants spend with their families and a deterioration in the quality of family life.

\section{The Breadwinner's Weekly Commute}

The distance of the breadwinner's renewed mobility may make the evening return home difficult or impossible. Consequently, their daily life is characterised by a re-separation from their reunited relatives because the weekly commute makes them move from their homes to work places in other provinces and sometimes regions. They may return only at weekends, making the long wished for and hard won family reunification little more than a hollow reality and formal achievement. This is the experience of Jalal:

I used to work in Marghera, nearby. Now, every week I must go to Ancona, La Spezia, Naples... 5 My company gets work in Naples and brings me there from here. Usually, I'm there all week and I come back home at the weekend. (Jalal, Bangladeshi applicant husband)

Similarly to what happens in the case of housing mobility and the forced renewal of cohabitation, the move of the breadwinner within national borders, from the province to the metropolitan areas, in search of work, could also be considered as a 'journey back' in his biography.

\section{International Mobilities}

The impact of the economic crisis has increased the 'permanent impermanence' of the migrants' family unity, often forcing them to a high level of mobility with significant repercussions on their daily family life. This mobility is often an inevitable and enduring condition and may even have an international character, which is both a form of agency, taking advantage of a wider area of opportunity, and a forced choice due to the lack of social and material opportunities. The interviews highlight the continued postponing of family unity and show the experiences of newly divided families waiting to be united once again.

\section{Reactivation of International Mobility: Onward Migration}

The crisis pushes many reunited families into a new migration towards other European countries, in search of better or more job opportunities (Giralt-Mas, 2017). This strategy may vary according to a number of factors including national origin, 'migration seniority', the presence or absence of extended family members in Italy or in other European countries, the age of children and home ownership status. Above all, this form of mobility 
is made possible by the acquisition of Italian citizenship, and, therefore, a European passport, which expands international horizons.

Migration from Morocco to Italy is one of the most established and dates back to the 1980s. As a consequence, many Moroccan migrant workers have been able to buy their homes, reunite their families and often re-build the extended family circle they have in the country of origin, not only through the formal process of family reunification, but also via other routes such as amnesties and labour migration entries. They have children who often are born in Italy, have completed their studies and are fully integrated into the local social fabric, and who are resistant to moving. For these families, a new migration journey of the whole reunited family is therefore a difficult decision and it is up to the breadwinner to try to resume his role, lost during the crisis, and migrate again, usually to France. This is the case, for example, of Kamal and Safaa's husband:

I will go [to search] for a job in France, then I will send remittances here. Hopefully. I must support my family and satisfy their needs. (Kamal, Moroccan applicant husband)

My husband will try to go to France to find work. We have relatives there. There's a crisis in Europe, but it is worse in Italy. For me it is better to stay here in Italy. Even the kids don't want to go. (Safaa, Moroccan reunited wife)

This new migration is experienced in a very different phase of life than when they left their country of origin and, again, it pushes migrants back on their migration journey. In the early 1980 s, respondents left Morocco, leaving their families but planning for reunification. Today, at this time of crisis, many leave their families again, undergoing further separations and experience of 're-transnationalisation'. As before, they keep on sending remittances to their families, not however from Italy to Morocco, but from France to Italy, that is the country of origin of their children - young adults belonging to the socalled 'second generation'. These migrants are no longer new husbands, young fathers or breadwinners for their family of origin, rather they are men in their 50s and parents of grown children. They are once again migrants without families in the (new) destination country, experiencing the emotional cost of the distance from their family.

In comparison to Moroccan migration to Italy, the Bangladeshi one originated later and it is only between the late 1990 s and early 2000 s that migrant families start to reunite. For these families, when the economic crisis started in 2008 and some of them chose to leave Italy, usually for the UK, this process was relatively more feasible and did not imply new separations as they often did not own their homes, have children of school or preschool age and live within a nuclear family. Kazu describes his plans:

Bangladeshi people really like Italy; however, the problem is the unemployment. So, many people are going to the UK. When they get a passport, they go to there to find work. I wouldn't like to change country. I would like to stay here, but if I don't find a job what shall I do? We should move. [...] All together, me, my wife and my child. (Kazu, Bangladeshi applicant husband)

The trajectories of the respondents show how the crisis has contributed to a change in the migration plan and to the phenomenon of 'onward migration' (Ahrens et al., 2016; 
Giralt-Mas, 2017; Rezaei and Goli, 2011; Toma and Castagnone, 2015; Van Liempt, 2011).

\section{The Dual Meaning of EU Citizenship}

Analysis of the international mobilities of migrant families requires a focus on naturalisation. Acquisition of citizenship has an instrumental and functional purpose; through citizenship, migrants can claim their right to stay, emancipating themselves and their family members from the condition of 'Gastarbeiter' and embodying the Simmelian archetype of the foreigner who 'comes today and remains tomorrow' (Carrillo, 2015; King and Mai, 2009). In Khalid's words:

I applied and got citizenship because my children were born here and I do not even think about going back to Morocco. There, I do not have friends anymore, I spend all my life here, I have nothing left there. [...] My children are not used to the Moroccan environment, culture, language. They were born and grew up in Italy and feel Italian. We cannot go back. [...] And citizenship is a security for the future, against deportation. (Khalid, Moroccan applicant husband)

Finally, as presented above, through the acquisition of Italian citizenship and, therefore, a European passport, migrants also claim their right to mobility (Danaj and Çaro, 2016; Della Puppa and Sredanovic, 2017; Faist, 2013; Glick Schiller and Salazar, 2013; Morokvasic, 2004). This becomes a necessity in the context of the economic crisis and a strategy for gaining better or additional work, as Apon states:

I'm going to leave Italy, because [here] there are difficulties. Here in Italy there has been this crisis for some years and I don't see a solution. I always said that I want to take advantage of the opportunity that the [Italian] passport gives me: to go away from here. (Apon, Bangladeshi applicant husband)

Modern citizenship appears increasingly modelled on the contingencies, concerns and plans for the future of individuals and families, and their instrumental uses, especially an intergenerational perspective of expanding opportunities: a strategically designed and formal act, which is practised in a functional way for specific aims, including an increase of motility (Kaufmann et al., 2004).

\section{Reunited Relatives' Temporary Return to Their Native Country}

With the crisis, while some families are not able to take advantage of onward migration (e.g. because of the lack of achievement of Italian citizenship), others may choose other forms of international mobility, such as the temporary return to their native country of wives and/or children. This mobility is intended to lighten the sponsor's burden of maintenance costs while waiting for a better job in Italy, which is similar to the findings of Spizer and Piper (2014) in the case of Filipino migrants.

This is the case for Hamza and Fatima's family. He arrived in Italy in 1989 and was reunited with her in 1998. When the interviews were carried out, Hamza was making his living with temporary, often underpaid jobs, after being made redundant as a construction 
bricklayer. Fatima was working as a housekeeper without a regular contract. They have sent their daughter back to their country of origin, where she will be looked after by her grandmother while they wait for an improvement in their employment situation:

This crisis puts us in trouble, we cannot live here in Italy... I mean me, my wife and my daughter. So, we sent her [the daughter] to Morocco where she's staying with my mother until the situation gets better. I'm looking for a new stable job, but all the construction sites have closed. (Hamza, Moroccan applicant husband)

This is also the case for Roton, a Bangladeshi first-migrant applicant who used to work in the local shipbuilding industrial district and also was made redundant. When the fieldwork took place he was working occasionally for small subcontracting companies that often sent him far from Venice. Therefore, his wife and son went back to Bangladesh, staying at his family's home and waiting for his employment to become less uncertain:

I sent them to the country because there is no work here. The crisis... Now I work a week in a month, if I am lucky, if they call me, if not... how can we live like this? [...] Here, I would spend on our home loan, food for three, taxes, everything. In Bangladesh, it costs less, so I sent them to my father's home, there's always something to eat, I had just to pay the flight and that's all. (Roton, Bangladeshi applicant husband)

It has been a 'journey back' in Roton's settlement and migration biography, as he is again experiencing being without family in the country of destination. However, his experience reveals that the survival strategies and mobility practised by migrant families often intersect. The breadwinner must undertake a frequent commute that takes him from the Province of Venice to various locations for work. As a result, he is now sharing the apartment with other fellow countrymen who also are without their families. Such mobility, however is not enough to preserve effective family unity.

\section{First Migrants' Temporary Return to Their Native Country}

The unemployment of the first migrant drives some family members to enter the labour market to supplement the family income and contribute to the fulfilment of the reunited family's needs. This is the case, for example, of Chadia and her family: 'I work as a housekeeper for five families. I have to work. I don't have any contracts. It's a bit hard but, unfortunately, I cannot stop: he [the husband] has been fired, laid off. He is unemployed' (Chadia, Moroccan reunited wife). As is clear from the interviews, these workers are employed within the informal economy, in the lower-paid and low-skilled segments of the labour market, without regular contracts or any respect for labour rights and safety standards. However, despite the precariousness of these jobs, as the first-migrant men became unemployed, the role of breadwinner was often assumed by their wives (Nadim, 2016; Wray, 2015), as Meriem tells:

He was in 'cassa integrazione' [a system where the state pays part of the salaries of employees of a company that is in difficulty], now he is just unemployed, no more salary, and I do everything, I'm the only one who works, as housekeeper and cleaner. [...] I don't have a regular 
contract, but do the cleaning in two houses and clean the stairs in a block of flats in this village. (Meriem, Moroccan reunited wife)

These instances of unemployment and lack of income can lead to the first migrant and former breadwinner temporarily returning to their native country, while their reunited spouses, having had access to the labour market working in the informal economy, chose to remain in Italy and support the children. This is the choice of Aicha:

My children were born and raised here, they go to school here, one is finishing his studies, they do not want to go to Morocco. My husband has been there for almost two months now and is deciding whether to come back here or stay in Morocco, or who knows... he is also thinking about France. (Aicha, Moroccan reunited wife)

This mobility trajectory is shaped by the 'migration seniority' of the reunited family and, consequently, by the age of the 'second generation' migrant children who were born and/ or raised in Italy. Furthermore, other issues should be considered: on the one hand, the return to the country of origin of the former breadwinner does not lead to an effective protection of family unity but, rather, involves new separations within the family. On the other hand, as underlined by Aicha, a Moroccan reunited wife, the temporary return to the country of origin by some members of the family intertwine with other migration plans, including onward migration to France.

\section{Conclusions}

This article has contributed to the under-researched theme of the link between the economic crisis and survival strategies and mobilities practised by migrant families to protect family reunification.

The crisis has caused a rupture in the biography of migrant families and their plans and may be turned into an opportunity to change trajectories and take further decisions about their future.

The crisis also reveals that migrant family unity does not represent a definitive and lasting achievement. On the contrary, it is a condition that must be constantly protected, by fulfilment of the requirements imposed by reunification policies (Bertolani et al., 2013; Bonizzoni, 2012, 2014). Migrant families must undertake various forms of mobility and redefine their daily geographies to maintain their housing, occupational and economic standards. On the one hand, the crisis has forced migrant families to reorganise their living situations to reduce expenses. For example, many families share a single flat with other people who are also experiencing the harshness of the crisis, resulting in a narrowing of domestic spaces and frequent interpersonal tensions. On the other hand, it has led to new forms of labour mobility, related to the daily and weekly commute of the breadwinner in search of new occupations to replace lost jobs.

The mobilities experienced by members of reunited families can also be deployed on an international level. The crisis can be addressed better in countries where migrants have stronger social ties offered by different migration contexts. These include new migration to Northern European countries by the breadwinner, a temporary return of 
reunited family members to their country of origin and even the temporary return of the first migrant himself, while other family members enter into the labour market often in the informal economy to replace the income previously provided by the breadwinner.

Such mobilities are shaped by a number of material, social, biographical and family factors. First of all, 'migration seniority' and its consequences in terms of the constraints and opportunities must be considered. A longer 'migration seniority', for example, characterised by families of Moroccan origin, results in greater social rootedness due to the presence of members of the extended family, home ownership and, above all, the complete socialisation of the 'second generations'. Their children were born or reunited in Italy, and are now embedded in the school context, friendship networks and local society. These factors constitute a capital of resources for coping with the crisis, but also a restriction on international mobility.

Among Moroccan families, settled in Italy for at least two generations, a hypothetical onward migration (Ahrens et al., 2016; Giralt-Mas, 2017; Rezaei and Goli, 2011; Toma and Castagnone, 2015; Van Liempt, 2011) would only be pursued by the first migrant, reactivating the sending of remittances to the family left behind in Italy. Similarly, a hypothetical temporary return to the native country as a strategy to optimise economic savings would also be pursued by the first migrant, due to the embeddedness of their grown children in the social fabric, their reunited wives' entry into the labour market and general social stabilisation, which also depends on 'migration seniority'.

Families that experienced more recent migration, such as the Bangladeshis, typically have a nuclear structure - also due to the 'forced nuclearisation' imposed by family reunification policies (Mustasaari, 2015) - and, above all, have children of school or preschool age. For this reason, it would be easier for them to practise onward migration involving the entire reunited family. However, a temporary return of the first migrant to Bangladesh would be less feasible because the reunited wife is commonly caring for young children and is therefore less able to enter the Italian labour market.

The acquisition of Italian citizenship plays a pivotal role in this mobility framework and constitutes part of a broader strategy of social and territorial stabilisation and a form of protection against deportation (King and Mai, 2009). It also appears to be the gateway to easier international mobility that could be experienced as a chosen goal or an enforced choice (Della Puppa and Sredanovic, 2017).

Furthermore, interviews reveal that different coping strategies and mobilities also intersect and overlap. For example, to optimise economic savings or recover their employment status, in the case of reunited relatives' temporary return to their native country, it is common for the first-migrant breadwinner to reorganise their own space by house sharing, practise daily or weekly commuting patterns or even look to other European countries, reactivating mobility.

These strategies often involve a 'journey back' along the migratory and biographic paths of first-migrant family members and the revival of his experiences during the first years of migration. He must live with other migrants, he is without his family in the country of destination, he again starts sending remittances to the family left behind.

On the one hand, migrant families are harshly hit by the crisis, on the other hand, they react proactively, exploiting their social resources, including social capital and mobility capital, to deal with the increased precariousness. However, reunited families 
are forced to separate again, experiencing a process of 're-transnationalisation' because of reactivated migration. This constitutes the paradox embedded in such mobilities that are contradictory and ambivalent. While the intention is to protect family unity in times of crisis, the implementation of these strategies drives families to compromise their family life.

\section{Acknowledgements}

This article is the result of a broader research carried out by the Laboratory for Social Research of the Ca' Foscari University in Venice. The research unit comprised Giuliana Chiaretti, Francesco Della Puppa Fabio Perocco and Ottavia Salvador. The author of this article would like to warmly thank the migrant families interviewed and the members of the research unit.

\section{Funding}

This research received no specific grant from any funding agency in the public, commercial or not-for-profit sectors.

\section{Notes}

1. Neighbourhood of Venice.

2. Neighbourhood of Venice.

3. The most important Italian shipbuilding company.

4. Town in the region of Friuli Venezia Giulia, 100 kilometres from Venice.

5. Respectively 370,360 and 720 kilometres from Venice.

\section{References}

Ahrens J, Kelly M and Van Liempt I (2016) Free movement? The onward migration of EU citizens born in Somalia, Iran, and Nigeria. Population, Space and Place 22: 84-98.

Ambrosini M (2014) Parenting from a distance and processes of family reunification: A research on the Italian case. Ethnicities 8: 1-20.

Andrijasevic R and Sacchetto D (2016) From labour migration to labour mobility? The return of the multinational worker in Europe. Transfer 2: 219-231.

Askola H (2016) Migrating for family care in later life: Senchishak v Finland, older parents and family reunification. European Journal of Migration and Law 3: 351-372.

Avila E and Hondagneu Sotelo P (1997) 'I'm here, but I'm there': The meanings of Latina transnational motherhood. Gender and Society 11: 548-571.

Awad I (2009) The global economic crisis and migrant workers: Impact and responses. Geneva: ILO.

Baldassar L (2014) Too sick to move: Distant 'crisis' care in transnational families. International Review of Sociology 24: 391-405.

Baldassar L and Merla L (2014) Transnational Families, Migration and the Circulation of Care. New York: Routledge.

Bertolani B, Rinaldini M and Tognetti Bordogna M (2013) Combining civic stratification and transnational approaches for reunited families: The case of Moroccans, Indians and Pakistanis in Reggio Emilia. Journal of Ethnic and Migration Studies 9: 1470-1487.

Bloemraad I (2004) Who claims dual citizenship? The limits of postnationalism, the possibilities of transnationalism, and the persistence of traditional citizenship. International Migration Review 2: 389-426. 
Boccagni P and Lagomarsino F (2011) Migration and the global crisis: New prospects for return? The case of Ecuadorians in Europe. Bulletin of Latin American Research 30: 282-297.

Bonifazi C and Marini C (2014) The impact of the economic crisis on foreigners in the Italian labour market. Journal of Ethnic and Migration Studies 3: 493-511.

Bonizzoni P (2012) Civic stratification, stratified reproduction and family solidarity: Strategies of Latino families in Milan. In: Kraler A, Kohli M and Schmoll C (eds) Gender, Generations and the Family in International Migration. Amsterdam: Amsterdam University Press, 311-335.

Bonizzoni P (2014) Immigrant working mothers reconciling work and childcare: The experience of Latin American and Eastern European women in Milan. Social Politics: International Studies in Gender, State \& Society 21: 194-217.

Bonizzoni P (2015a) Uneven paths: Latin American women facing Italian family reunification policies. Journal of Ethnic and Migration Studies 41: 2001-2020.

Bonizzoni P (2015b) Here or there? Shifting meanings and practices in mother-child relationships across time and space. International Migrations 6: 166-182.

Bonizzoni P and Boccagni P (2013) Care and circulation revisited: A conceptual map of diversity in transnational parenting. In: Baldassar L and Merla L (eds) Transnational Families, Migration and the Circulation of Care. London: Routledge, 78-94.

Bragg B and Wong LL (2016) 'Cancelled dreams': Family reunification and shifting Canadian immigration policy. Journal of Immigrant \& Refugee Studies 1: 46-65.

Bryceson D and Vuorela U (2002) The Transnational Family: New European Frontiers and Global Networks. Oxford: Berg.

Bustamante JJ and Alemàn C (2007) Perpetuating split-household families: The case of Mexican sojourners in mid-Michigan and their transnational fatherhood practices. Migraciones Internacionales 4: 65-86.

Carling J, Menjivar C and Schmalzbauer L (2012) Central themes in the study of transnational parenthood. Journal of Ethnic and Migration Studies 38: 191-217.

Carrillo D (2015) Politics and group belonging: Predictors of naturalisation behaviour in France. Journal of Ethnic and Migration Studies 12: 1932-1957.

Castles S, De Haas H and Miller MJ (2013) The Age of Migration: International Population Movements in the Modern World. New York: Guilford Press.

Champion T and Shuttleworth I (2017) Are people changing address less? An analysis of migration within England and Wales, 1971-2011, by distance of move. Population, Space and Place. Epub 6 April 2017. DOI: 10.1002/psp.2026.

Clark AV, Duque-Cavache R and Palomare-Linares I (2017) Place attachment and the decision to stay in the neighbourhood. Population, Space and Place. Epub 6 March 2107. DOI: 10.1002/ psp.2001.

Codini E and D'Odorico M (2007) Una nuova cittadinanza: per una riforma della Legge del 1992. Milan: FrancoAngeli.

Colombo E, Domaneschi L and Marchetti C (2011) Citizenship and multiple belonging: Representations of inclusion, identification and participation among children of immigrants in Italy. Journal of Modern Italian Studies 3: 334-347.

Danaj S and Çaro E (2016) Becoming an EU citizen through Italy: The experience of Albanian immigrants. Mondi Migranti 3: 95-108.

Della Puppa F and Sredanovic D (2017) Citizen to stay or citizen to go? Naturalization, security and mobility of migrants in Italy. Journal of Immigrant and Refugee Studies 15(4): 366-383.

Dreby J (2006) Honour and virtue: Mexican parenting in the transnational context. Gender and Society 20: 32-59.

Eggebø H (2010) The problem of dependency: Immigration, gender, and the welfare state. Social Politics: International Studies in Gender, State \& Society 3: 295-322. 
Faist T (2013) The mobility turn: A new paradigm for social sciences? Ethnic and Racial Studies 11: $1637-1646$.

Favell A (2014) The fourth freedom: Theories of migration and mobilities in 'neo-liberal' Europe. European Journal of Social Theory 3: 275-289.

Fresnoza-Flot A (2009) Migration status and transnational mothering: The case of Filipino migrants in France. Global Networks 9: 252-270.

Fullin G and Reyneri E (2011) Low unemployment and bad jobs for immigrants in Italy. International Migration 49: 118-147.

Giralt-Mas R (2017) Onward migration as a coping strategy? Latin Americans moving from Spain to the UK post-2008. Population, Space and Place. Epub 6 April 2017. DOI: 10.1002/ psp.2017.

Glick Schiller N and Salazar NB (2013) Regimes of mobility across the globe. Journal of Ethnic and Migration Studies 2: 183-200.

Jackson Y, Varcher Herrera M and Gascon J (2014) Economic crisis and increased immigrant mobility: New challenges in managing Chagas disease in Europe. Bulletin of the World Health Organisation 10: 771-772.

Kaufmann V, Bergman MM and Joye D (2004) Motility: Mobility as capital. International Journal of Urban and Regional Research 4: 745-756.

Kilkey M and Merla L (2014) Situating transnational families' care-giving arrangements: The role of institutional contexts. Global Networks: A Journal of Transnational Affairs 14: 210-229.

King R and Mai M (2009) Italophilia meets Albanophobia: Paradoxes of asymmetric assimilation and identity processes among Albanian immigrants in Italy. Ethnic and Racial Studies 1: $117-138$.

Kofman E and Raghuram P (2015) Gendered Migrations and Global Social Reproduction. London: Palgrave.

Kraler A (2009) Family Migration in Europe. Policies vs. Reality. Amsterdam: Imiscoe.

Lafleur JM and Stanek M (eds) (2017) South-North Migration of EU Citizens in Times of Crisis. Switzerland: Springer Open.

Martin P (2009) Recession and migration: A new era for labor migration? International Migration Review 3: 671-691.

Morokvasic M (2004) 'Settled in mobility': Engendering post-wall migration in Europe. Feminist Review 77: 7-25.

Mosern C and Horne P (2015) Does economic crisis always harm international migrants? Longitudinal evidence from Ecuadorians in Barcelona. International Migration 2: 274 290.

Mustasaari S (2015) The 'nuclear family paradigm' as a marker of rights and belonging in transnational families. Social Identities 21: 359-372.

Nadim M (2016) Undermining the male breadwinner ideal? Understandings of women's paid work among second-generation immigrants in Norway. Sociology 50(1): 109-124.

Parreñas RS (2001) Servants of Globalization: Women, Migration, and Domestic Work. Stanford, CA: Stanford University Press.

Parreñas RS (2005) Children of Global Migration: Transnational Families and Gendered Woes. Stanford, CA: Stanford University Press.

Parreñas RS (2008) Transnational fathering: Gendered conflict, distant discipline and emotional gaps. Journal of Ethnic and Migration Studies 34: 1057-1072.

Rezaei S and Goli M (2011) Should I stay or should I go? The emigrating immigrants. International Journal of Business and Globalisation 6: 229-250.

Ryan L (2011) Transnational relations: Family migration among recent Polish migrants in London. International Migration 49: 80-103. 
Sacchetto D and Vianello FA (2013) Migrants coping with the economic crisis: Romanian and Moroccan workers in Italy. Journal of International Migration and Integration 17(3): 839852.

Schweitzer R (2015) A stratified right to family life? On the logic(s) and legitimacy of granting differential access to family reunification for third-country nationals living within the EU. Journal of Ethnic and Migration Studies 41: 2130-2148.

Spitzer DL and Piper N (2014) Retrenched and returned: Filipino migrant workers during times of crisis. Sociology 48(5): 1007-1023.

Strasser E, Kraler A, Bonjour S, et al. (2009) Doing family: Responses to the construction of 'the migrant family' across Europe. History of the Family 14: 165-176.

Tilly C (2011) The impact of the economic crisis on international migration: A review. Work, Employment and Society 4: 675-692.

Toma S and Castagnone E (2015) What drives onward mobility within Europe? The case of Senegalese migration between France, Italy and Spain. Population 70(1): 65-96.

Triandafyllidou A (2014) Migrant livelihoods during the Greek crisis: Coping strategies and the decision to return. Mondi Migranti 3: 7-29.

Van Liempt I (2011) 'And then one day they all moved to Leicester': The relocation of Somalis from the Netherlands to the UK explained. Population, Space and Place 17: 254-266.

Wray H (2015) 'A thing apart': Controlling male family migration to the United Kingdom. Men and Masculinities 4: 424-447.

Francesco Della Puppa holds a PhD in Social Sciences at the Department of Philosophy, Sociology, Pedagogy and Applied Psychology of the University of Padua. He is researcher at the Department of Philosophy and Cultural Heritage and member of the Master's Programme on 'Migration Phenomena and Social Transformations' of Ca' Foscari University in Venice. His research interests include the process of migrant family reunification, engendering migration, young people of migrant origin; onward migrations; migrant labour; Bangladeshi diaspora; refugees.

Date submitted February 2017

Date accepted February 2018 